\title{
Sánchez Rodríguez, V. (2020). Bailando ante el mundo. La participación del Grupo de Coros y Danzas de Ciudad Real en la Feria Mundial de Nueva York (1965). Ciudad Real: CIOFF España, 240 pp. ISBN: 978-84-87087-73-8
}

El conocimiento del pasado, incluso cuando vivimos circunstancias excepcionales como las que nos rodean actualmente, resulta fundamental como germen de nuestra sociedad, de ahí la relevancia de las investigaciones sobre esta temática. A este respecto, el estudio del folklore y de las manifestaciones populares de carácter oral pueden darnos una idea del modo de vida de nuestros antepasados y hacernos conscientes de los vestigios culturales que les rodearon e incluso del origen de nuestras tradiciones.

Ese es el contexto de la novedad editorial que aquí se reseña, titulada Bailando ante el mundo. La participación del Grupo de Coros y Danzas de Ciudad Real en la Feria Mundial de Nueva York (1965), de la Doctora en Musicología Virginia Sánchez Rodríguez, profesora de la Universidad de Castilla-La Mancha e investigadora del Centro de Investigación y Documentación Musical (CIDoM)-Unidad Asociada al CSIC. La autora -que ha sido ampliamente galardonada y becada por varios de sus trabajos sobre música y cine, sobre la presencia de la mujer en la historia de la música y sobre música popular de carácter tradicional- presenta aquí el estudio resultante de la Beca de Investigación en Folklore otorgada por el Consejo Internacional de Organizaciones de Festivales de Folclore y de las Artes Tradicionales (CIOFF) en colaboración con el Instituto Nacional de las Artes Escénicas y de la Música, que fue concedida a la doctora Sánchez Rodríguez en su edición del año 2018.

El volumen, de 240 páginas, está dedicado a la labor de los grupos de Coros y Danzas de España que tanta actividad desarrolló, especialmente, durante el franquismo, profundizando en el estudio de un caso: la agrupación de la localidad de Ciudad Real y su participación en un acontecimiento supranacional, como la Feria Mundial de Nueva York del año 1965. A través de ocho capítulos temáticos, y tomando como núcleo el diario de viaje de uno de los componentes del grupo que acudió hasta la localidad norteamericana y varias colecciones fotográficas de aquel momento, se presenta un trabajo que aúna lo histórico y lo musical y que se caracteriza por el rigor académico, por su entretenida lectura y por la profusión de ilustraciones.

Tras una introducción, en la que se exponen los principales aspectos metodológicos del trabajo, se incluye el primer capítulo, que lleva por título "La Sección Femenina: de la enseñanza musical a las agrupaciones de Coros y Danzas de España" y que significa una presentación sobre la intensa y heterogénea labor musical de la mencionada institución, con 
especial atención al contexto de los Coros y Danzas de España. El segundo capítulo, "La Feria Mundial de Nueva York 1964-1965 y la joya española", muestra, de forma general pero bien documentada, el origen y la esencia de esta exposición universal desarrollada en la ciudad de los rascacielos, mientras en el tercer capítulo, "Los espectáculos del Pabellón de España: un nuevo espacio para el lucimiento de artistas vinculados al folklore", se presenta la diferente visibilidad de la música tradicional de las diferentes regiones de España frente al flamenco en el contexto sociocultural de la época y también en la mencionada Feria Mundial de los años 1964 y 1965.

Posteriormente, el capítulo 4, "De La Mancha a Manhattan: la agrupación de Coros y Danzas de Ciudad Real llega a la Feria Mundial de Nueva York", se centra en los orígenes y la idiosincrasia de la agrupación manchega, la protagonista del volumen, y en cómo se produjo la llegada de este grupo de jóvenes, procedentes de una pequeña capital de provincia, a este evento internacional para dar a conocer los cantos y bailes tradicionales de su región a todo el mundo a través de este evento. Por su parte, en el capítulo 5, "Las actuaciones musicales del grupo de Coros y Danzas de Ciudad Real en el Pabellón de España", se presenta la intensa actividad performativa, mientras en el sexto, "El repertorio de Coros y Danzas de Ciudad real interpretado en la Feria Mundial", se analizan, exponen y transcriben los vestigios de los principales géneros entonados y bailados por los componentes.

El capítulo 7, "Más allá del Pabellón de España", muestra que los vestigios folklóricos de La Mancha estuvieron presentes en la sociedad norteamericana también fuera de la cita expositiva, señalando, además, una serie de vivencias sociales de los componentes de los Coros y Danzas de Ciudad Real, siempre junto a agrupaciones de otras regiones del país. Por su parte, el octavo capítulo, titulado "La despedida de la Feria y la recepción de la participación neoyorquina de Coros y Danzas de Ciudad Real", no solo recoge las circunstancias que rodearon el cierre de la Feria y las últimas actuaciones del grupo, sino también la repercusión local posterior. Al fin y al cabo, el hecho de que un grupo mixto de veinteañeros se convirtieran en embajadores de la música y la danza de su tierra en una urbe como Nueva York, que era vista en la España de los años sesenta como una de las principales potencias del mundo, es un hito que ha sido recordado por las generaciones posteriores. Por último, el volumen finaliza con las conclusiones y con la relación de las profusas fuentes utilizadas para la elaboración de la investigación, que incluye fuentes documentales y bibliográficas diversas y apropiadas.

Si bien es cierto que el libro profundiza en el estudio de un caso concreto -la mencionada agrupación manchega y su participación en la citada Feria Mundial-, este trabajo, a través de una estructura piramidal invertida, permite recrear la visibilidad de la música española de tradición oral durante los años sesenta del siglo XX en España y también comprobar el modo en que estos sonidos fueron utilizados como elementos propagandísticos del país en el extranjero a través de citas internacionales. Por todo ello, sin duda, este volumen no solo resultará inspirador para otros investigadores que aborden temas similares, sino que, además, permitirá al lector obtener un mayor conocimiento sobre 
RESEÑAS DE LIBROS

la presencia de la música tradicional española y su divulgación, con distintos fines, en un evento supranacional como la Feria Mundial de Nueva York de 1964-1965.

Cristina Plaza Sánchez

Universidad Complutense de Madrid 